
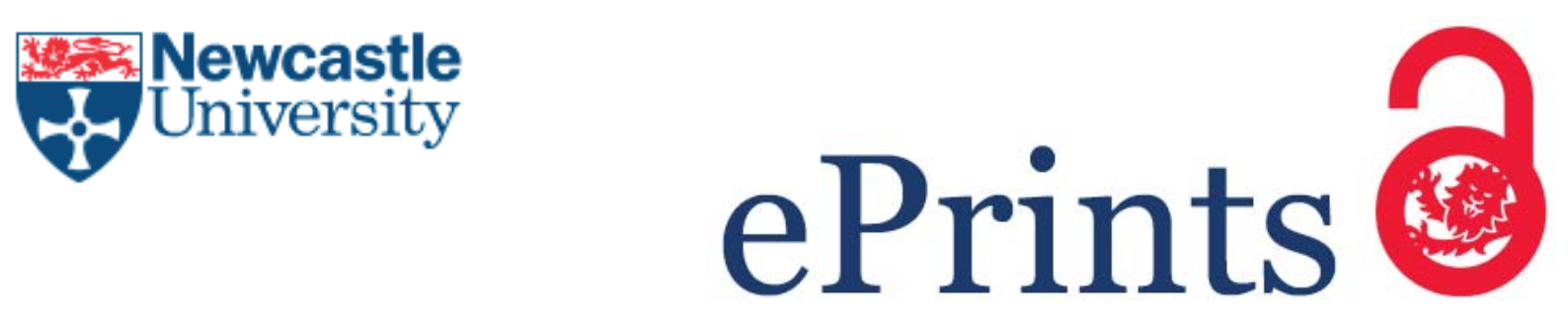

Hamza N, Elkerdany D, Pendlebury J, Imam S, ElSadaty A, ElSerafi T.

Sustained Liveability: A framework beyond Energy Conscious Building

Conservation of Market Halls.

International Journal of Architectural Research 2017, 11(3), 119-131.

\title{
Copyright:
}

Copyright 2017 Neveen Hamza. This work is licensed under a Creative Commons AttributionNonCommercial-NoDerivatives 4.0 International License.

DOI link to article:

http://dx.doi.org/10.26687/archnet-ijar.v11i3.1381

Date deposited:

$30 / 11 / 2017$

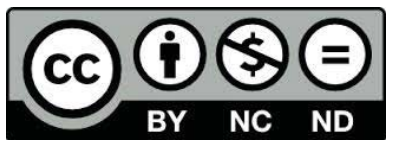

This work is licensed under a

Creative Commons Attribution-NonCommercial-NoDerivatives 4.0 International licence 


\title{
ArchNet

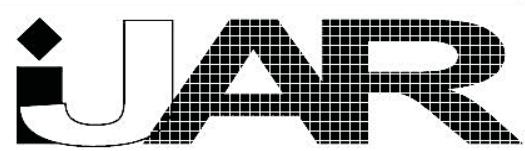

Archnet-IJAR: International Journal of Architectural Research

www.archnet-ijar.net/ -- https://archnet.org/collections/34

\section{SUSTAINED LIVEABILITY: A FRAMEWORK BEYOND ENERGY CONSCIOUS BUILDING CONSERVATION OF MARKET HALLS}

DOI: http://dx.doi.org/10.26687/archnet-ijar.v11i3.1381

\author{
Neveen Hamza, Dalila EIKerdany, John Pendlebury, Sahar Imam, \\ Aliaa AISadaty, Tamer EISerafi
}

\section{Keywords}

historic market halls; sustainable heritage, creative economy; Attaba vegetable market

ArchNet-IJAR is indexed and listed in several databases, including:

- Avery Index to Architectural Periodicals

- EBSCO-Current Abstracts-Art and Architecture

- CNKI: China National Knowledge Infrastructure

- DOAJ: Directory of Open Access Journals

- Pro-Quest

- Scopus-Elsevier

- Web of Science

\section{Abstract}

Market halls are commonly found in contexts of cultural and heritage value. Positioned in urban centres and transport networks, these unique buildings were originally constructed in the 19th century to ensure better food distribution in growing European cities, then copied to other territories such as Egypt. We argue that leaving market halls, with their large spanning structures and indoor open space, for dilapidation is a lost opportunity for sustaining community engagement, and educating the public on the original sustainability, neighbourhood regeneration and cultural thinking that underpinned these buildings. The proposed framework extends current sustainable 'heritage conservation frameworks' beyond concepts of adding renewable energy technologies, recycling and sustainable goods movement, to 'sustaining liveability and social inclusion'. We argue that market halls offer the opportunities to merge the daily activities of buying and selling food with creating local creative economies such as culinary art exhibitions, and culinary schools. The paper consists of two parts: the first discusses the historical urban context of market halls in Cairo; the second proposes a sustainable heritage conservation model for market halls.

N. Hamza*, Senior Lecturer, School of Architecture, Planning and Landscape, Newcastle University, Newcastle, NE1 7RU, UK

D. ElKerdany, Professor, Department of Architecture, Faculty of Engineering, Cairo University, Cairo, Egypt

J. Pendlebury, Professor, School of Architecture, Planning and Landscape, Newcastle University, Newcastle, NE1 7RU, UK

S. Imam, Associate Professor, Department of Architecture, Faculty of Engineering, Cairo University, Cairo, Egypt

A. AlSadaty, Assistant Professor, Department of Architecture, Faculty of Engineering, Cairo University, Cairo, Egypt

T. ElSerafi, Lecturer, Department of Architecture, Faculty of Engineering, Cairo University, Cairo, Egypt

*Corresponding author: neveen.hamza@newcastle.ac.uk 
Neveen Hamza, Dalila EIKerdany, John Pendlebury, Sahar Imam, Aliaa EISadaty, Tamer EISerafi Archnet-IJAR, Volume 11 - Issue 3 - November 2017 - (119-131) - Regular Section

\section{INTRODUCTION}

In the $19^{\text {th }}$ Century, 'Market Hall' buildings were presented to the public as strategic urban additions in Europe and in countries under European influence, including Egypt. Market hall buildings presented great aspirations of a moral architecture that served a social purpose for meeting and exchanging trade, with a specific emphasis on the quality of food supply to the urban population (Scmiechan and Carls, 1999).

Fava (2017) argues that in large cities such as Barcelona, the appearance of a network of market halls alongside other types of outdoor street markets and the department store were not in economic competition but rather strengthened the cultural and economic identity of the city centre. Similar to market halls in Europe the existence of the market halls in Cairo followed an organizational ambition of the ruling royal family and the city council to improve the food offered in a modern building. These market halls would spare no expense to provide clean and healthy environments, while acting as social meeting points in the new westernized quarter of Cairo. Market halls emerged in the urban environments to strengthen the aspect of providing social engagement through the acts of buying and selling.

Fava argued that, from the nineteenth century, the system of public markets acquired considerable importance and was considered a basic service of the metropolis in urban planning policy. Retailing, and especially food retailing, has always been a fundamental element for the organization of the compact and more liveable city furthering the relations of proximity (URBACT, 2015). The significance of heritage value of the market hall is reflected in its cohesive architectural fusion between engineering ingenuity of its large wrought iron structures, rational use of building materials, passive environmental design, order and cleanliness, and a progressive change from the squalor of open markets. Currently, in Cairo, market hall buildings are being left to deteriorate, and their original function as quality food providers is being jeopardized due to a lack of municipal regulations to safeguard the diversification of offerings and the conservation of their function as food retailers. This is creating a dangerous precedent for loss of the sustainability, identity, cultural and social values that were conferred by the existence of these market halls.
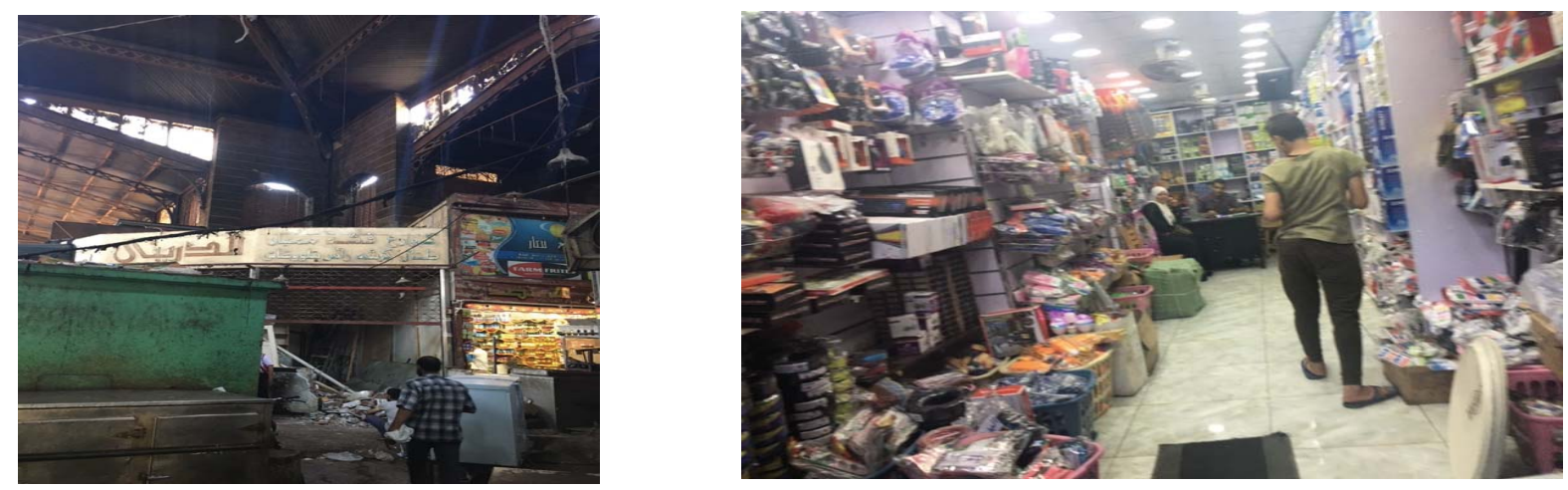

Figure 1. Destruction of food stalls (left), new electrical and phone accessory stalls (right) (Source: Authors).

In Egypt, liberal trade policies and faster modes of transportation and delivery of goods, along with suburban growth and the accompanying commercial "sprawl", undermined the conservation of market halls. Contrary to the leading social and economic role that market 


\section{$\operatorname{ArchNet}[\mathbf{A R}$}

halls played in sustaining culinary and cultural activities, for example in Barcelona and Italian market halls, stalls in market halls in Cairo were not governed by regulations. Increasingly, they are losing their function and diversity of culinary offerings to stalls offering electrical goods and mobile phone accessories imported from China (Figure 1).

Traditional conceptions of heritage conservation focusing narrowly on building fabric are increasingly being challenged and broadened to encompass integrated approaches focused upon sustaining the 'liveability' of a building. Conservation and heritage management are conceived as value-based activities and there is a focus upon what is significant about a building or place that makes it worthwhile of protections (Gibson \& Pendlebury, 2009). In the case of the market halls, this is integrally linked to their traditional use and technologies. The loss of the traditional tenants focused on food retailing is leading to a loss of the building's sustainability, identity, cultural and social values.

The Ford Foundation (in Florida, 2002) states "Public markets are a vehicle for social integration and upward mobility", highlighting that what separates public markets from other economic development projects is that a good public market is not only a local economic engine, but also a social gathering place that builds community. Urban regeneration is the attempt to reverse socio-economic decline by improving the physical structure of the built heritage aiming for a better economy. Therefore, we argue that there is an opportunity to move building conservation beyond a singular attempt to valorise building fabric, or a particular building use, to a more integrated strategy that repositions market halls as a focal point for educating the public about sustainable strategies, as well as a space for cultural exchange and art appreciation through exhibition activities.

The presence of market halls in Egypt dates back to the second half of the $19^{\text {th }}$ century. By the 1890s, the market halls in Europe faced considerable competition from new-fashioned department stores and chain stores. One factor deflecting popular sentiment away from the public markets was that governments downgraded the priority they gave to improving the public food supply. Towns focused their resources on sanitary reform, gas and water, slum clearances, and public housing projects. As a result, some market halls were allowed to deteriorate to the point of public embarrassment (Scmiechan and Carls, 1999). In Egypt, the 'Attaba vegetable market hall', is a typical building of its age and urban significance in Egypt: a $19^{\text {th }}$ century historical building which is currently losing its architectural significance due to uncontrolled change to its urban context, and internal spaces left to marginalized urban squatter occupants. This research looks to create a holistic framework that would pave the way for improving the built heritage to regenerate the building's economic prosperity, while using its central positioning in the city fabric to house temporary artistic and cultural events related to food production, consumption, and food art as a social catalyst in the multicultural city centre of Cairo.

\section{MARKET HALLS AS TANGIBLE AND INTANGIBLE HERITAGE}

Watson (2009) highlights the role of markets in providing places for meeting and engagement and as a significant factor in place attachment, presenting a site of everyday sociality and public space where people from different cultures connect through casual encounters as both traders and shoppers. Halbwachs (1992) draws attention to how place and groups receive the imprints of each other. The physical presence of these historic markets create mental maps of place and way finding, and support collective memory that 

Archnet-IJAR, Volume 11 - Issue 3 - November 2017 - (119-131) - Regular Section

resides in everyday communication taking place between customers, vendors and passersby, an essential role in maintaining community identity.

We argue that historic markets are social spaces that, if well preserved and managed, can play a major role in strengthening local community ties, attract visitors, and erase boundaries between groups of different ethnicities, classes and ideological backgrounds. However, if not regenerated sensitively, they could easily feed into the undesirable impacts of the neighbourhood gentrification process.

Site visits by the team in winter and summer of 2016 revealed that the market halls experience gradual changes due to lack of policy implementation, public spending initiatives and squatter activities. The buildings, along with their urban fabric, experience daily vandalism and a complete lack of maintenance and sanitary services.

\section{Historic green markets as experience/creative economies}

Europe has given much attention to the potential role of historic market halls in redeveloping urban districts. Several cities such as Barcelona, Milan, Budapest and many German cities have aimed at valorising and reinforcing the integration of historic markets within their surrounding urban contexts. Such projects deal with historic markets as the economic backbone of many towns, highlighting their role as venues for social exchanges and cohesion between community members (URBACT, 2015).

Historic markets represent a rich ground for two growing fields in cultural economics: experience economy and creative economy. The term 'experience economy' was coined by Pine and Gilmore (1998) where they argued that people search for memorable experiences and events, and that the experience becomes the product itself. Historic markets are venues with the most social diversity; they attract people of different ages, genders and backgrounds. Thus, the act of buying, selling and creating food is socialization between different levels that cannot be found in regular modern supermarkets. This act, in fact, transforms the market from a venue for exchanging goods and money to 'an engine for community life' (Panozzo, 2013).

In Florence (Figure 2), the refurbishment of the San Lorenzo Market completed in 2015, provided a unique and rich experience that encompasses the entertainment, the education, and the aesthetic experiences. The remit of the market extended from merely the vending of fresh produce and dry foods, to offer an experience of social engagement with cooked food shared in the food court that becomes an end in itself. The creation of a food culinary school acts to preserve the cherished Tuscan cuisine recipes, and is a popular facility. A plastic removable canopy divides the internal height of the space to trap heat from cooking activities and people, to warm the large open space with less energy demand in winter, a functional and educational addition focused on energy consciousness in practice. 


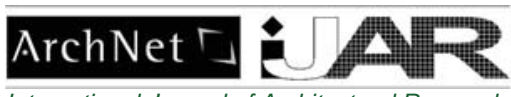

International Journal of Architectural Research

Neveen Hamza, Dalila EIKerdany, John Pendlebury, Sahar Imam, Aliaa EISadaty, Tamer EISerafi Archnet-IJAR, Volume 11 - Issue 3 - November 2017 - (119-131) - Regular Section
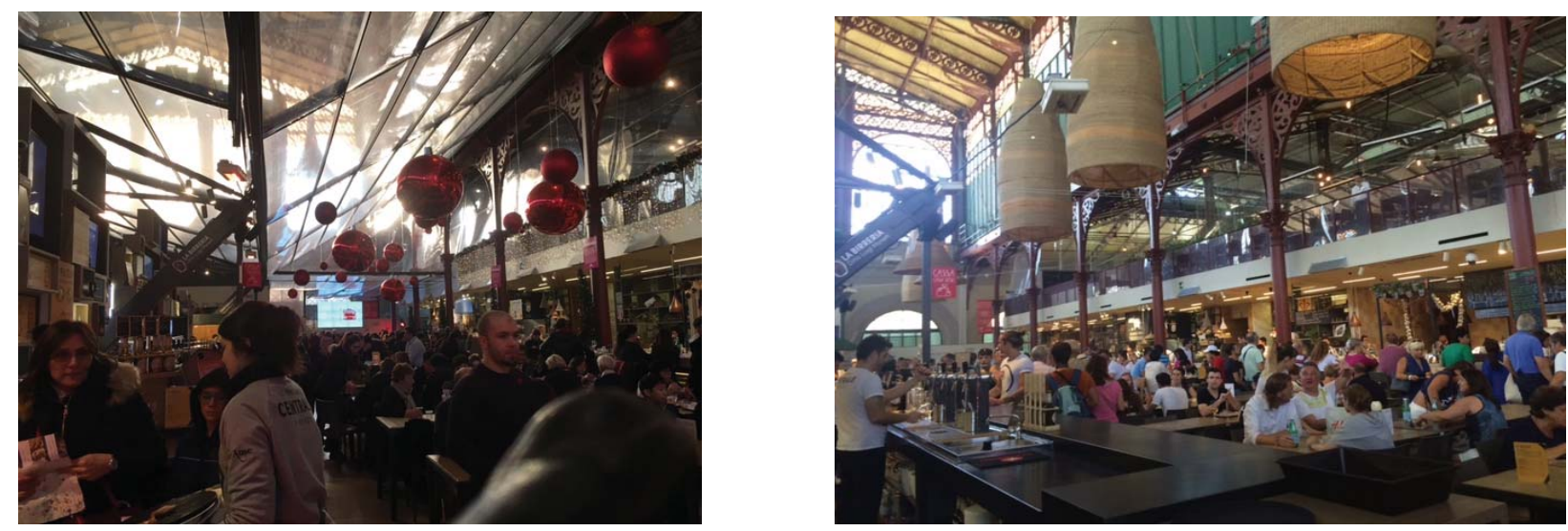

Figure 2. San Lorenzo Market in winter (Left) and in summer (right) (Source: Authors).

The infrastructure of the $19^{\text {th }}$ century, including factories and warehouses, is being transformed creatively into cultural venues that provide events and offers entertainment. The opportunities offered by such valuable places and buildings increase the experience value by maintaining their identity, and encouraging customers to be involved in the experience (Lorentzen, 2009).

Creative economy is based on the idea that creative cultural activities can exploit city spaces and exploit the cultural potentials of historic districts. Thus, historic markets can be seen as a potential venue for the development of creative economy strategies. People from very different backgrounds and income gather under the same roof, which is a basic element of both experience economy and creative environment. Therefore, historic market buildings, if used as cultural venues or creative spaces, can be a benefit not only to the building, but also to its surrounding context (Imam, 2013).

\section{THE $19^{\text {TH }}$ CENTURY MARKET HALLS OF CAIRO: THE CASE OF THE ATTABA VEGETABLE MARKET}

The $19^{\text {th }}$ century witnessed major changes in Cairo's urban history. Egypt began a modernization policy under the rule of Muhamed Ali Pasha (1805-1848), followed by Ismail Pasha (1863-1879) (Stewart, 1999). Modernization of the capital was represented in new urban developments such as new avenues and squares, following the Paris Haussmannian model (Raymond, 2001). Many new building types were introduced, and among them, the covered market halls.

Cairo underwent the 'Dream of Westernization' under its ruler Isma'il Pasha (1863-1879) where plans were drawn for an enlarged and embellished Cairo as a symbol and showpiece of Egypt's progress (Raymond, 2001). Cutting through the old cemetery lands and the traditional archaic street layouts on the borders of the old Islamic city, the creation of Mohammed Ali Street (which borders the South entrance to the market hall) and the Azhar road, created a new node for the construction for the new vegetable market hall of El Attaba. Alazhar Street connected the market with older traditional markets in Muski, Gamaleya and Hamzawi, while Mohamed Ali Street connected Attaba square to the Citadel.

This urban development was followed by a colonial period from 1882-1936 during which occurred the intensification of Isma'il Pasha's project to create two cities side by side - one 


\section{$\operatorname{ArchNet} \square: \mathbf{A R}$}

International Journal of Architectural Research

Neveen Hamza, Dalila EIKerdany, John Pendlebury, Sahar Imam, Aliaa EISadaty, Tamer EISerafi Archnet-IJAR, Volume 11 - Issue 3 - November 2017 - (119-131) - Regular Section

westernized and one traditional. These two cities would differ even in the layout of their streets, and the market halls would act as nodes of cultural as well as economic significance. The creation of these new market halls paved the way for the newly constructed gridiron 'modern areas', which were heavily influenced by European planning philosophies, to thrive on the western side of the old city (Figure 3).

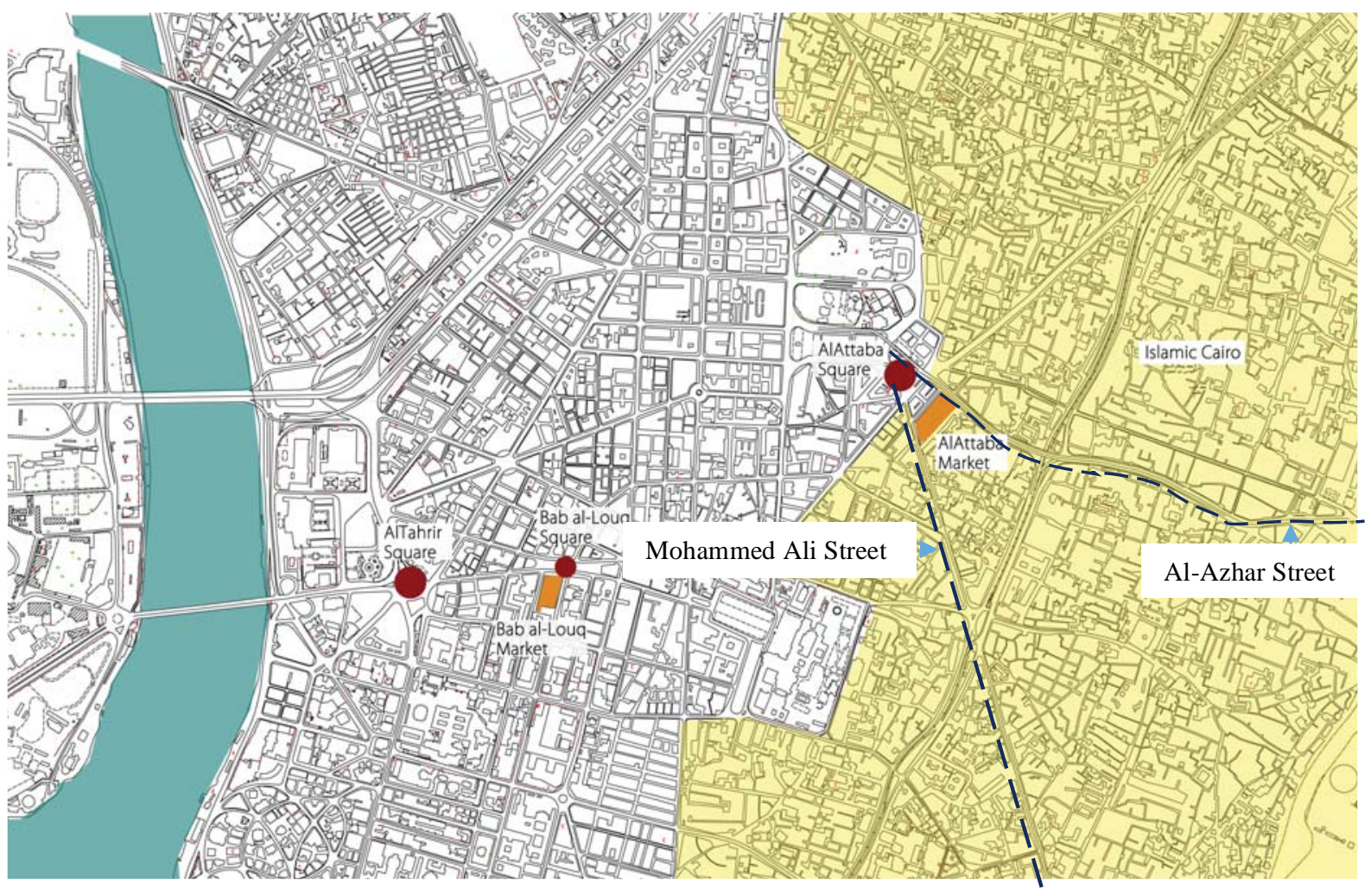

Figure 3: Gridiron (westernized) planning of the $19^{\text {th }}$ century Cairo between the Nile to the west and the Islamic Quarters to the East. Note the central positioning of the market Halls (circles) between the two quarters (source, Qala Historical archive, with author's superimposed analysis)

Attaba square borders the old traditional city and the new European quarter, creating a perfect roundabout for carriages, trams and automobiles. Six of the city's eight tramlines started at Ataba. The tram connected older market spaces in Muski, Gamaleya and Hamzawi to the new Ismailia quarter. The Attaba area served as the heart of the city and had many treasured heritage buildings along its boundaries including mixed tribunals, central fire station, police station, post office and department stores, Parliament Hotel, Matatia building, and food markets like 'Ataba market' (Raymond, 2001).

According to the historical endowment manuscript (Record 3711) found at the archival documentation centre at Dar al-Mahfuzat al-'Omoumeya at the Citadel, the building was a Waqf Khairy of the Khedive Tawfiq, a 'waqf' (an endowment, pl. awqaf). A 'Waqf' is defined by the Oxford Dictionary as an endowment made by a Muslim to a religious, educational or charitable cause; its origin in Arabic relates to the literal translation of 'stoppage, immobilization' of ownership of property for the sake of beneficiaries. Awqaf properties, to the present, represent a significant number of historic buildings in Cairo. The document written in Arabic states that the Khedieve embarked on building the market hall between 


\section{$\operatorname{ArchNet} \square: \mathbf{A R}$}

International Journal of Architectural Research

Neveen Hamza, Dalila EIKerdany, John Pendlebury, Sahar Imam, Aliaa EISadaty, Tamer EISerafi Archnet-IJAR, Volume 11 - Issue 3 - November 2017 - (119-131) - Regular Section

1886 and 1892, on a piece of vacant land previously used as a burial ground; burials were halted a few decades earlier as the city borders were expanding. The document states that two state departments bid for the construction of the market to the Ministry of Works (construction) at the time. Gran Bek, the general manager of the Cities and State Buildings Department, led the first while Franz (Bek) from the Endowments Department led the second. Interestingly, although it was more expensive, the Ministry of Works choose the bid by Gran Bek (57,000 LE) over Franz Bek (44,694 LE), because it included budgets for sanitary and building services, and extensions of the electricity and gas networks to the building; thus signalling a desire for a state of the art building with no expenses spared. The winning bid suggested spending a substantial (5000 LE) for covering the alleyways in the market.

Attaba Market was built using a neo-classical style for its main entrances to the two primary covered alleys, the longest running from north to south and the shortest running from east to west. Both alleys bring together four principal pavilions consisting of fourteen secondary alleys running parallel to the short alley (Figure 4). Each of the four pavilions had a specialty: butcher shops, a fish market, the sale of fruits and vegetables, and a spice and grocery market. Two smaller pavilions housed bakeries (Reynolds, 2012).

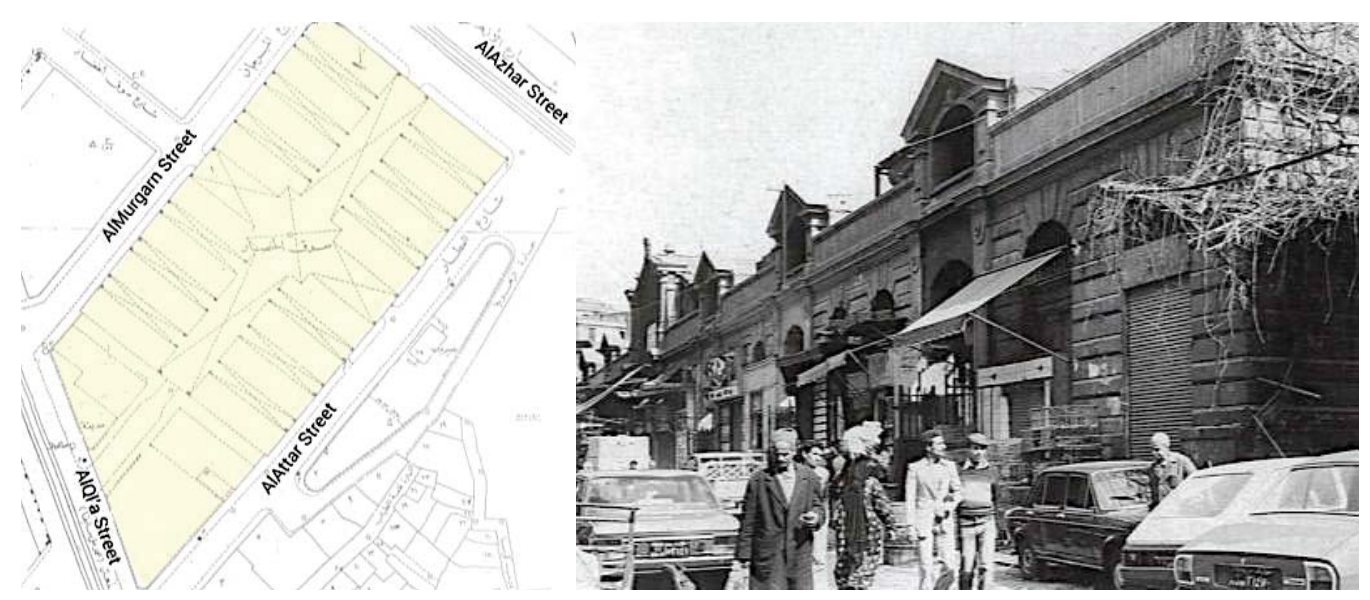

Figure 4. (Left) plan showing the main alleys and the secondary alleys in the vegetable market in Ataba (Source: Archives of AlAwqaf, 2017); (Right) market elevation (Source: Authors).

The Document states that the building had four facades, bordered by Al-Murgan Street from the west; Al-Attar Street from the east; Muhammed Ali Street from the South; and Al-Azhar Street from the North. The Market had an entrance gate from each of these streets. Furthermore, the document states that beside the southern gate, on Muhammed Ali, there was a park and a hideout. The manuscript states also that the whole market included 220 shops.

Interpreting the document it appears the shops that opened from outside varied in sizes, as they are described as being distributed as follows: 14 shops at al-Murgan Street; 15 shops at Al-Azhar Street; only 3 shops at Al-Attar Street; and only one shop at Muhammed Ali Street. The latter had access from Muhammed Ali Street and from the inside of the building.

A trussed roof higher than the shops flat roof covered the alleyways. The sides of the trussed alleyways contained arched openings to allow for lighting and ventilation as well as reducing 


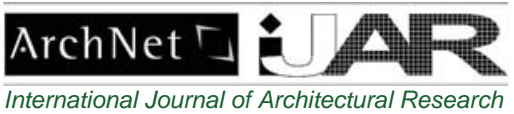

Neveen Hamza, Dalila EIKerdany, John Pendlebury, Sahar Imam, Aliaa EISadaty, Tamer EISerafi Archnet-IJAR, Volume 11 - Issue 3 - November 2017 - (119-131) - Regular Section

the structural load of these walls. A cast iron truss and a wooden roof, which projected over the clerestory openings to shade from the high levels of direct solar radiation, covered the main alleyways (Figure 5).
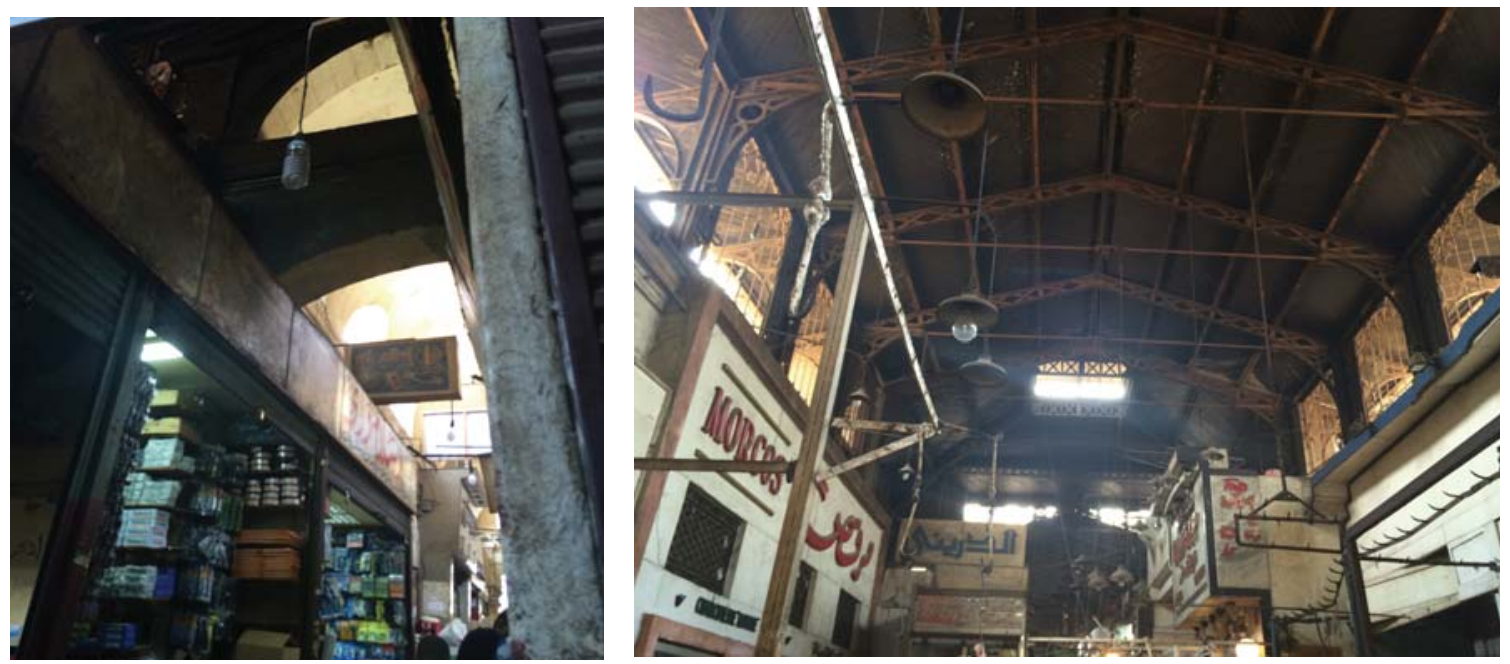

Figure 5. The Clerestory to provide natural daylight and ventilation inside the building: Left, the secondary alleyways; Right, the main Alleyway trusses and side openings (Source: author's collection).

\section{Aspects of Change}

After the 1952 Revolution, Downtown Cairo started to change and lose some of its fine urban qualities for many reasons. Historic buildings were subject to rent freezes and fragmented ownerships (e.g. one apartment could be owned by six or seven brothers and sisters) resulting from policies that forced land reform. This led to the rapid deterioration of several buildings due to a lack of maintenance. Many buildings changed their functions over the years, from residences to offices and clinics due to rent problems, without providing proper maintenance needed for such activities (El-Shafei, 2010). The increase of density; demographic changes; the loss of iconic buildings like the Opera house, Shepheard hotel, and Matatia building; and the change of uses from residential to administrative caused many public buildings to fall into decay, and resultantly transformed the cultural heart of Cairo to a deteriorating area with heavy traffic (EI Kadi, 2012).

Change in urban regulations affected land values, and many districts of cultural value suffered from the destruction and damage that occurred, due to these changes in regulations not considering this aspect of an area's value. Some of the buildings were demolished; most were modified through additions and infill structures in setbacks, resulting in the streets losing a lot of their architectural character.

The 'Ataba vegetable market' and the Parliament hotel buildings suffered from a sprawl of electronic trade covering their facades, with no respect to any regulations, adding a second skin and almost completely covering the aesthetics of the building (Figure 6). 


\section{$\operatorname{ArchNet} \square: \mathbf{A R}$}

International Journal of Architectural Research

Neveen Hamza, Dalila EIKerdany, John Pendlebury, Sahar Imam, Aliaa EISadaty, Tamer EISerafi Archnet-IJAR, Volume 11 - Issue 3 - November 2017 - (119-131) - Regular Section

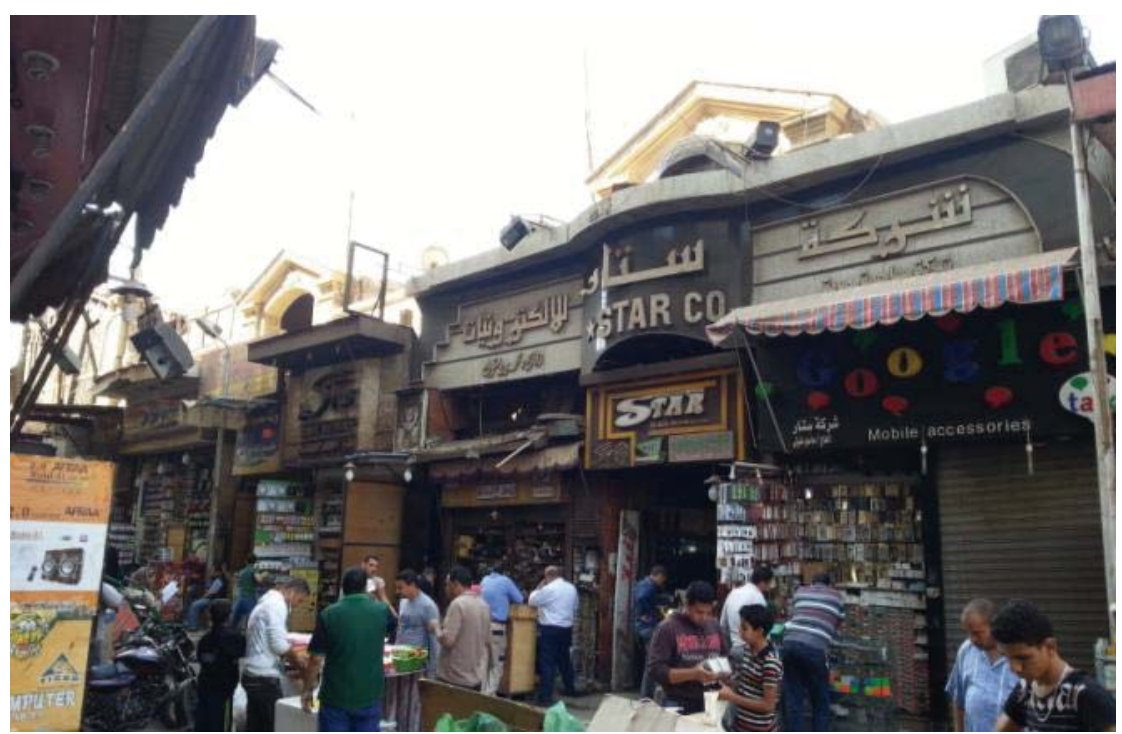

Figure 6. The second skin added to the building covering its aesthetics (Source: Authors).

Successive visits to the market in 2016-2017 revealed illegal extensions encroaching on the alleyway, substantially narrowing the passages between shops, which causes an impediment of the circulation of people and goods, and a blockage of the sewage system originally designed to provide a healthy environment. Additionally the blocking of the clerestory arches above the original alleys causes poor airflow inside the building (Figure 7).

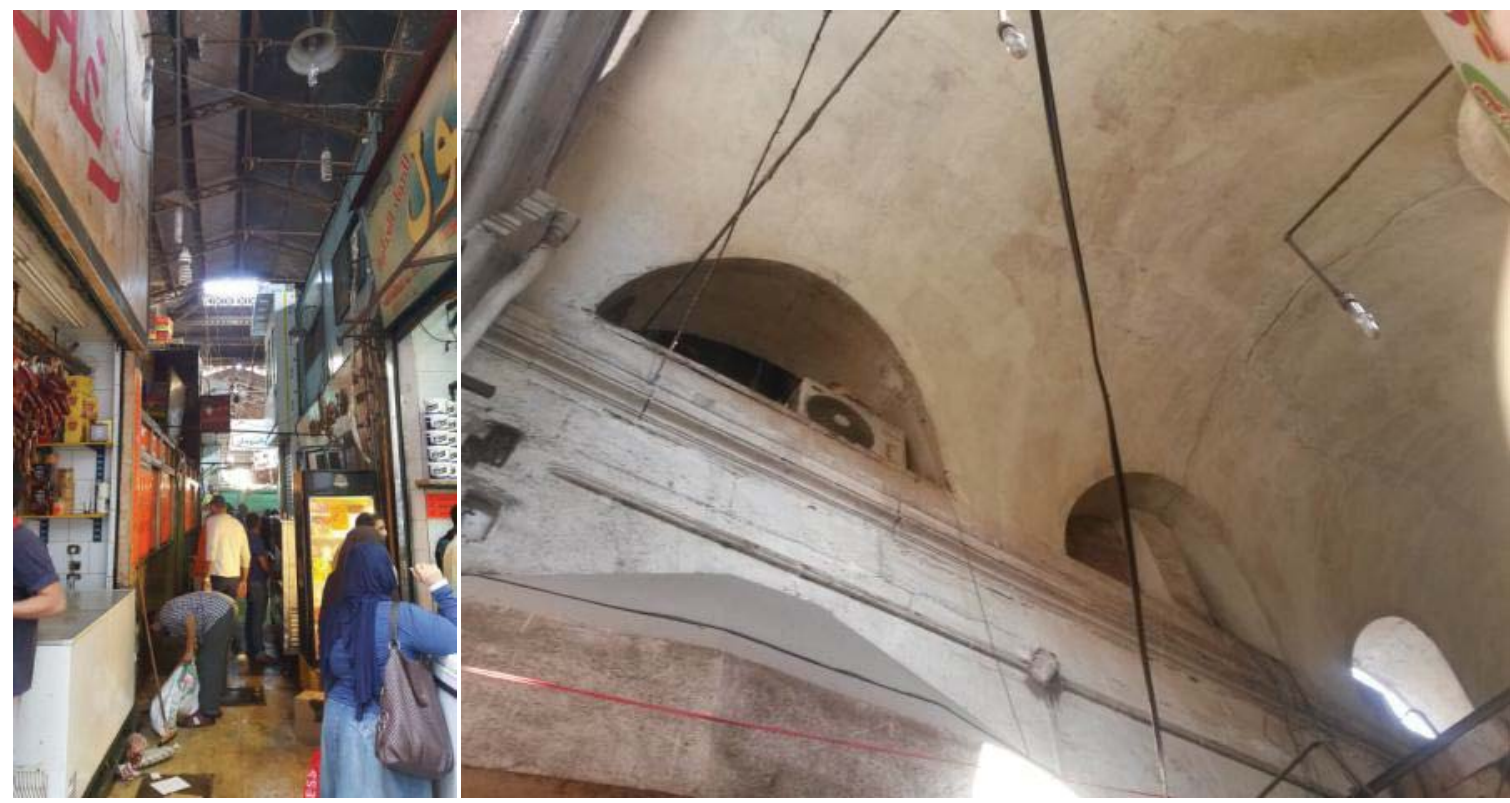

Figure 7. (Left) narrowed alleys (Source: author's collection); (Right) blockage of clearstory windows inside of the building (Source: Authors).

Thus, currently, movement inside the building is difficult to negotiate, both socially and functionally. Very few users go inside the Attaba market; footfall is severely affected leaving the inside being used for delivery and the wholesale vending purposes. In contrast, the 


\section{$\operatorname{ArchNet} \square: \mathbf{A R}$}

International Journal of Architectural Research

Neveen Hamza, Dalila EIKerdany, John Pendlebury, Sahar Imam, Aliaa EISadaty, Tamer EISerafi Archnet-IJAR, Volume 11 - Issue 3 - November 2017 - (119-131) - Regular Section

outside of the building provides a high intensity of users; it is a real hectic and vibrant atmosphere. Thus, users mainly experience the unplanned extensions on the periphery of the building, not the historic building itself, which represent a lost opportunity and paves the way for collective memory loss of this building's existence behind the haphazard frontal extensions.

\section{INFORMING A SUSTAINING LIVEABILITY’ FRAMEWORK:}

The research adopts a three-phase methodology:

1- Use of archival research and secondary literature to understand the existence of market halls of cultural and historical value in Cairo, and to understand the current state of conservation frameworks;

2- Engagement with local authorities and vendors to record their collective perceptions and understandings of the cultural and historic context and value of the market; participant observations have been carried out and a direct questionnaire has been taken by $45 \%$ of the stall owners;

3- Team research meetings to formulate the expected outcomes and trajectories to deliver a sustainable conservation framework beyond building fabric conservation, and a recommendation to add particular renewable energy technologies to reduce energy demand.

The third step led to an agreement on expected roles:

- Policy makers will help in accessing archival material, and engage with the Cairo Governorate to set policies for Market Hall conservation.

- Engagement with the civilians in society as the aggregate of non-governmental organizations. In the market hall, these were found to comprise of two groups: the owner vendors who have inherited their stall businesses with some being the third generation in their family to hold the stall; and the second being vendors who were employed and had little appreciation or understanding of the historic value of the buildings.

- Our role as 'Academia' is for the creation and dispersion of knowledge, as well as the testing and evaluation of the application of this framework to other market halls in Cairo.

Historically, the focus of much building conservation was upon the retention of building fabric and the reversibility of any intended fabric changes, as evidenced by the material authenticity of buildings as historical cultural documents. As conservation has become a much more extensive activity, a greater people-focus has emerged. The Burra Charter, developed by Australia ICOMOS (2013, but originally developed in 1979) still emphasizes the role of heritage as physical historical records of expressions of identity, experience, and cultural significance. The Burra Charter was an important landmark in recognizing the importance of the voice of non-expert constituents in defining the value of heritage, which in turn relates to an understanding of heritage as a social practice and integral to issues of identity and experience.

At the same time heritage and conservation are increasingly institutionalized and seen as a means to achieve economic and neighbourhood-regeneration policy objectives. This might involve, for example, hyper-commodification of the building as part of strategies for tourist development (Pendlebury, 2015). More progressively, heritage might be used to aid processes of socially inclusive regeneration (Pendlebury et. al., 2004). 'Sustainable 


\section{ArchNet ${ }_{\lrcorner}$}

International Journal of Architectural Research

Neveen Hamza, Dalila EIKerdany, John Pendlebury, Sahar Imam, Aliaa EISadaty, Tamer EISerafi Archnet-IJAR, Volume 11 - Issue 3 - November 2017 - (119-131) - Regular Section

conservation' adds another dimension to the principles, interpreted by Pendlebury et. al. (2014) as opportunities to integrate heritage building conservation with energy conservation principles and renewable energy technologies. Here we would like to extend this value system to assessing the 'liveability' of heritage conservation; a principle that extends heritage conservation to a physical, environmentally responsible, social policy essential to progressive cultural provision and culinary identities. We argue that this information is required to generate any digital building information models for heritage.

\section{A SUSTAINABLE LIVEABILITY HERITAGE FRAMEWORK}

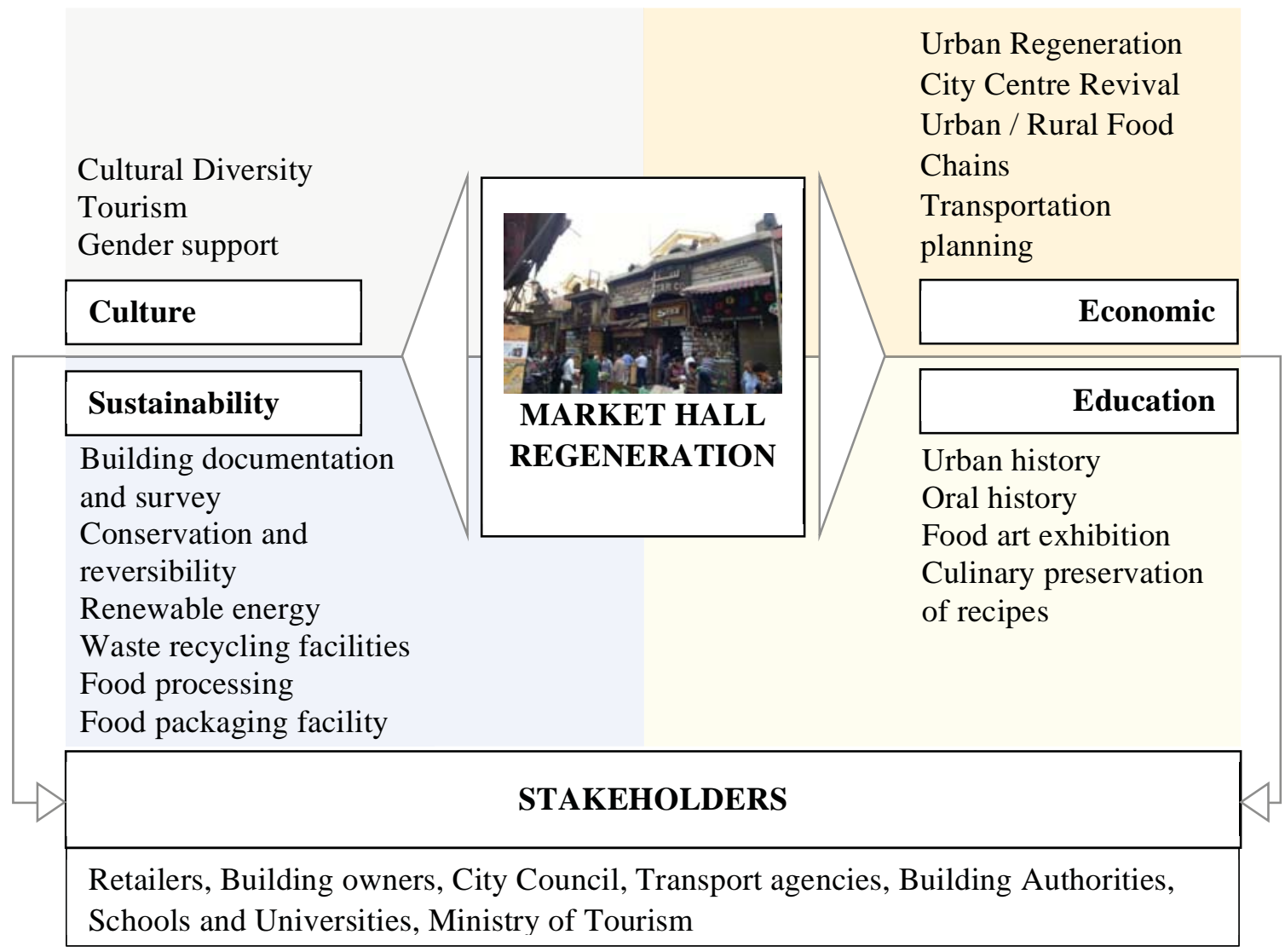

Figure 8: A framework for market hall 'liveability' beyond sustainability (Source: Authors).

Figure 8 depicts extending the challenges of building conservation, social inclusion and energy conservation to include the potential role of market halls as generators of educational and cultural experiences, leading to the continuation of local culinary appreciation, food art and a space for exhibitions.

Recent temporary use strategies consider art and culture as tools to revive existing contexts of value. These buildings are often used as a backdrop for artistic endeavours due to the temporality aspect of these activities, which allows for experimenting and an experiential experience of art through community involvement. Therefore, including such activities in old 
Neveen Hamza, Dalila EIKerdany, John Pendlebury, Sahar Imam, Aliaa EISadaty, Tamer EISerafi Archnet-IJAR, Volume 11 - Issue 3 - November 2017 - (119-131) - Regular Section

historic buildings as an adaptive reuse policy helps protect and maintain the historical building, and is an influential tool for addressing social development strategies. Temporary activities are also considered as experimental projects that can change areas' economic conditions by attracting investments and visitors (Imam, 2013).

We argue that market halls may represent a catalytic pivot in their locations, attracting new types of users and changing the image of decaying contexts of value. To achieve a sustainable goal that is all inclusive of sustaining 'liveability of the building and its users', a comprehensive framework coordinating and linking building owners, stall vendors, building services managers, policy makers, educational and tourism authorities needs to be integrated.

\section{CONCLUSIONS}

Markets as buildings are tangible pieces of heritage that witness daily consumer and vendor patterns, casual encounters and sociality of space, and are a scene for multi-cultural exchanges. These buying and selling activities, with their changes through time, create the intangible heritage of a culture's sounds, smells, and a value system of what a community appreciates.

Current conservation frameworks focus on singular aspects. A true 'Sustainable Conservation' framework needs to expand to 'Liveability of Heritage conservation', beyond the usual challenges of conserving building fabric and aesthetics or merely the call to add renewable energies or recycling facilities, to considering market halls as arenas for cultural experiences.

Historical market halls, with their large cast iron truss constructions and strategic positioning in historical city centres, offer a major opportunity to expand existing activities of food buying and selling to experiences of culinary art and the conservation of local culinary recipes through the creation of cooking schools. Due to their centrality in the urban fabric, market halls also create an opportunity for inclusion of exhibition space to educate the public and tourists alike.

\section{ACKNOWLEDGEMENTS}

This paper is jointly funded by the UK, Arts and Humanities Research Council (AHRC- grant reference AH/N009169/1Sustainable Green Markets) and the Egyptian Sciences, and Technology Development Fund (STDF); under the Newton-Mosharafa Fund. The first author was also supported by a Newton-Mosharafa fund to undertake the initial visits and research team engagement: Newton-Mosharafa fund (165346057). The authors are also grateful for the Postgraduates students of the Department of Architecture, Faculty of Engineering, Cairo University who helped in the visual material used in this paper. Special thanks to Dr. Mahmoud Abdallah for his persistent efforts in finding the original endowment documents of the market.

\section{REFERENCES}

The Attaba Waqf endowment document:

Waqf endownment document The Attaba سنة 1303 هـ ربت 


\section{$\operatorname{ArchNet} \square: \mathbf{A R}$}

International Journal of Architectural Research

Neveen Hamza, Dalila EIKerdany, John Pendlebury, Sahar Imam, Aliaa EISadaty, Tamer EISerafi Archnet-IJAR, Volume 11 - Issue 3 - November 2017 - (119-131) - Regular Section

The Burra Charter. (2013). Burra Charter: The international council on monuments and sites ICOMOS Charter for Places of Cultural Significance. Canberra: Australia.

---. (1941-1942). Document no. 32/358/17582, pp. 80-90, at. Cairo, Egypt: Dar al-Mahfuzat al'Omoumeya at the Citadel.

El Kadi, G. (2012). Cairo: Center in Movement. Marseille: IRD Editions.

El-Shafei, K. (2010). "Downtown reborn? The Ismaelia Consortium's vision for urban regeneration". (M. Strasser, Interviewer) Al-Masry Al-Youm, Available at: http://www.egyptindependent.com.

Gibson, L. \& Pendlebury, J. (2009). Valuing Historic Environments. Oxford: Routledge.

Florida, R. (2002). The Rise of The Creative Class (and how it's transforming work, leisure, community and everyday life). New York, USA: Basic Books.

Halbwachs, M. (1992). On Collective Memory. Chicago and London: The University of Chicago Press.

Imam, S. (2013). Creative Economy and Urban Transformation in Developing Countries. Journal of Engineering and Applied Science, Faculty of Engineering, Cairo University, 60(6).

Lorentzen, A. (2009). Cities in the experience economy. European Planning Studies, 17(2).

Panozzo, F. (2013). Policy Paper on the role of Urban Markets for Local Development and Urban Regeneration. EU: A project implemented through the CENTRAL EUROPE Programme cofinanced by the ERDF. Retrieved from: www.centralmarkets.eu

Pendlebury, J. (2015). Heritage and Policy. In: Waterton, E., \& Watson, S (Eds.). The Palgrave Handbook of Contemporary Heritage Research (pp 426-441). London: Palgrave Macmillan.

Pendlebury, J., Hamza, N., Sharr, A. (2014). Conservation Values, Conservation Planning and Climate Change. DISP - The Planning Review, 50(3), pp.43.54.

Pendlebury, J., Townshend, T.G., Gilroy, R. (2004). The Conservation of English Cultural Built Heritage: A Force for Social Inclusion? International Journal of Heritage Studies, 10(1)

Pine, B., II, \& Gilmore, J. (1998). Welcome to the experience economy. Harvard Business Review, 76(4), 97-105.

Raymond, A. (2001). Cairo: city of history. Cairo, Egypt: American University Press in Cairo.

Reynolds, N. (2012 ). A City Consumed: Urban Commerce, the Cairo Fire, and the Politics of Decolonization in Egypt . Stanford, California: Stanford University Press.

Stewart, D. (1999). Changing Cairo: The political Economy of Urban Form. International Journal of Urban and Regional Research, 23(1), p128.

URBACT. (2015). Urban markets: heart, soul and motor of cities - Making city markets the drivers of sustainable urban development. Barcelona: City of Barcelona Institut Municipal de Mercats de Barcelona (IMMB). Retrieved from http://urbact.eu/sites/default/files/urbact_markets_handbook_250315.pdf accessed 4/4/2017

Watson, S. (2009) Brief Encounters of an Unpredictable Kind: Everyday Multiculturalism in Two London Street Markets, in Wise, A.; Velayutham, S., Everyday Multiculturalism. London: Palgrave Macmillan. 